\title{
Effects of different stressors on laying rate and selected blood indices in reproductive ducks
}

\author{
Helena Kontecka', J.M. Książkiewicz ${ }^{2}$ and L. Nogowski ${ }^{3}$ \\ 'Department of Poultry Breeding, Agricultural University \\ Wolyńska 33, 60-637 Poznań, Poland \\ ${ }^{2}$ Department of Waterfowl Breeding, \\ Research Institute of Animal Production \\ Dworzyska, 62-035 Kórnik, Poland \\ ${ }^{3}$ Department of Animal Physiology and Biochemistry, \\ Agricultural University \\ Wolyńska 35, 60-637 Poznan். Poland
}

(Received 2 July 1998; accepted 19 November 1998)

\begin{abstract}
The influence of some stressors on laying rate and selected haematological indices, and the corticosterone level in duck blood were studied. The experiment was carried out in the reproductive season (April - July) on 84 of Peking ducks. One control and three experimental groups were formed. All ducks were fed standard complete diets ad libitum for 8 wceks. In the 9 th week, blood samples were taken from birds and the following stress factors were introduced: in group II - restricted feeding ( $70 \mathrm{~g}$ of feed per bird per day) for a period of one week, in group III - addition of $20 \mathrm{~g} \mathrm{NaCl} / \mathrm{kg}$ during a period of one week, in group IV - withdrawal of water for two days. In the 10th week, blood samples were taken from ducks and during the next 5 weeks, all four groups were fed the standard diet $a d$ libitum. The following parameters were estimated in blood: hacmoglobin, hacmatocrit, red and white cell counts (proportion of granulocytes and agranulocytes) and corticosterone level. During the entire period of the experiment ( 14 weeks), the number of eggs laid in groups was recorded daily.

Substantial decreases in the laying rate in group II (restricted feeding) and in group IV (lack of access to water) were noted. Most haematological indices in duck groups did not differ significantly. In group IV, a significant increase of the heterophil:lymphocyte ratio /HLR/ from 0.74 to 2.63 was noted, as well as the highest level of corticosterone in blood in comparison with the control and feed-restricted groups.

It can be concluded that the restriction of feed exerted the highest and longest negative influence on the laying rate of ducks. Also, the two-day lack of access to water was found to have been very stressful to ducks. The $20 \mathrm{~g}$ of $\mathrm{NaCl}$ per $\mathrm{kg}$ added to the diet had little influence on the laying rate and also on the value of HLR.
\end{abstract}

KEY WORDS: duck, stress, laying rate, haematological indices, corticosterone 


\section{INTRODUCTION}

In the intensive breeding system, birds are exposed to different kinds of factors causing stress. Some are regarded as inevitable, as for instance: catching and handling birds according to veterinary requirements and planned technological operations. The external response of birds to stress manifests itself mostly by unrest, decrease or lack of appetite, decrease in body weight, increased susceptibility to diseases and a higher mortality rate. Physiological symptoms of stress include increased corticosterone secretion and changes in circulating leukocytes, i.e. a decrease in lymphocyte count and increase in heterophil count (Mitchell et al., 1992; Maxwell, 1993).

Intensive and prolonged stress exert a negative effect on the productivity and salubrity of birds and do not promote their well-being (Zulkifli and Siegel, 1995). For this reason, breeders should aim to eliminate or limit the negative influence of stress factors and also to prevent their occurrence.

The aim of this study was to investigate the influence of the most common stressors appearing in production connected with feeding on laying rate and on some haematological indices and the corticosterone level in the blood of ducks.

\section{MATERIAL AND METHODS}

The experiment was carried out on 84 Peking ducks, 40 weeks old, during the reproductive season that started in January. It covered 14 weeks of laying, from April to July. The birds were divided into 4 groups of 21 ducks and 3 drakes each (in 3 replications).

All groups of ducks were kept in a windowless building without access to the fowl-run. Environmental conditions, including the light program, complied with the obligatory rules of duck breeding. All birds were fed a standard complete diet for ducks, containing $17.4 \%$ crude protein and $11.3 \mathrm{MJ}$ of metabolisable energy per $\mathrm{kg}$. The diet was composed of (in \%): wheat 55 , barley 10 , soyabean oilmeal 16 , meat-and-bone meal 8 , dried grass, fat concentrate and limestone 3 each, dicalcium phosphate and vitamin-mineral premix 1. The food, except for group II during week 9, was given ad libitum. At the beginning of the 9 th week blood samples (A) were taken from each duck and different stressors were introduced for a one week period. The control group was fed as before. The feed in group II was restricted to $70 \mathrm{~g} / \mathrm{bird} /$ day, which amounted about $25 \%$ of the ad libitum intake. The diet given to ducks of group III was supplemented with $20 \mathrm{~g}$ of $\mathrm{NaCl}$ per $\mathrm{kg}$. The birds in group IV were deprived of access to water for the last 2 days of this week. At the beginning of the 10th week blood samples were again taken (B) and for the next consecutive 5 weeks, all groups were fed the standard diet ad libitum. The number of eggs was recorded daily for each group. 
Blood samples were taken from the wing vena ulnaris cutanea of every female. Heparin was used as an anticoagulant. The following blood parameters were determined: the haemoglobin content $(\mathrm{Hb})$, haematocrit index $(\mathrm{Ht})$, red blood cell count $(\mathrm{Rbc})$, white blood cell count $(\mathrm{Wbc})$ and thrombocyte count $(\mathrm{Tbc})$. White blood cells $(\mathrm{Wbc})$ were differentiated into granulocytes (heterophils, eosinophils and basophils) and agranulocytes (lymphocytes and monocytes). The ratio of heterophils to lymphocytes (HLR) was calculated.

$\mathrm{The} \mathrm{Hb}$ level in blood was determined using the cyanomethaemoglobin method (Pinkiewicz, 1971), and Ht index using the microhaematocrit method. The Rbc, Wbc and Tbc counts in $1 \mathrm{ml}$ of blood were performed under a microscope. Blood smears were stained using the Pappenheim method (MGG) following Bomski (1989) and then, using a microscope, $100 \mathrm{Wbc}$ were counted distinguishing granulocytes and agranulocytes. According to Bomski's formulas (1989), the mean volume of red blood cell (MCV), mean weight of haemoglobin per red cell $(\mathrm{MCH})$ and mean haemoglobin concentration in red cells (MCHC) were calculated. The plasma corticosterone level $(\mathrm{CN})$ was estimated by a radioimmunological method using the ImmunoChem-Double Antibody (ICN Biomedicals, Inc., USA) kit.

The data was subjected to variance analysis. The significance of differences between groups was statistically verified by the Duncan multiple range test and Student $t$ - test.

\section{RESULTS}

The laying rate of ducks in successive weeks of the experiment is presented in Figure 1. Up to the 8 th week (Table 1), the average laying rate in all groups was similar (62.7-69.7\%). After introduction of stressing factors in the 9th week, the laying rate decreased (Figure 1 and Table 1) and in group II and III was significantly lower than in the control group. From the 10th to 14th week the laying rate increased gradually (Figure 1) in groups exposed to stress, remaining, however, significantly lower than in the control group. The lowest laying rate $(14 \%)$ was recorded in group II, slightly higher, $27.8 \%$, in group IV.

The Rbc count in blood (Table 2-A) was similar in all groups before the introduction of the stress. After the period of stress (Table 2 -B) a significant increase in the Rbc content in the blood of ducks of group IV was observed. The $\mathrm{Hb}$ content in ducks exposed to stress increased significantly in groups III and IV. However, the $\mathrm{Hb}$ concentration differed significantly only in group IV $(7.77 \mathrm{mmol} / \mathrm{L})$ in comparison with group I $(7.22 \mathrm{mmol} / \mathrm{L})$. The $\mathrm{Ht}$ value, indicating the total content of morphotic elements in blood, underwent no changes in the studied groups of ducks, with the exception of group IV. The mean value of Ht in blood of ducks from group IV increased significantly in comparison with the value recorded before 


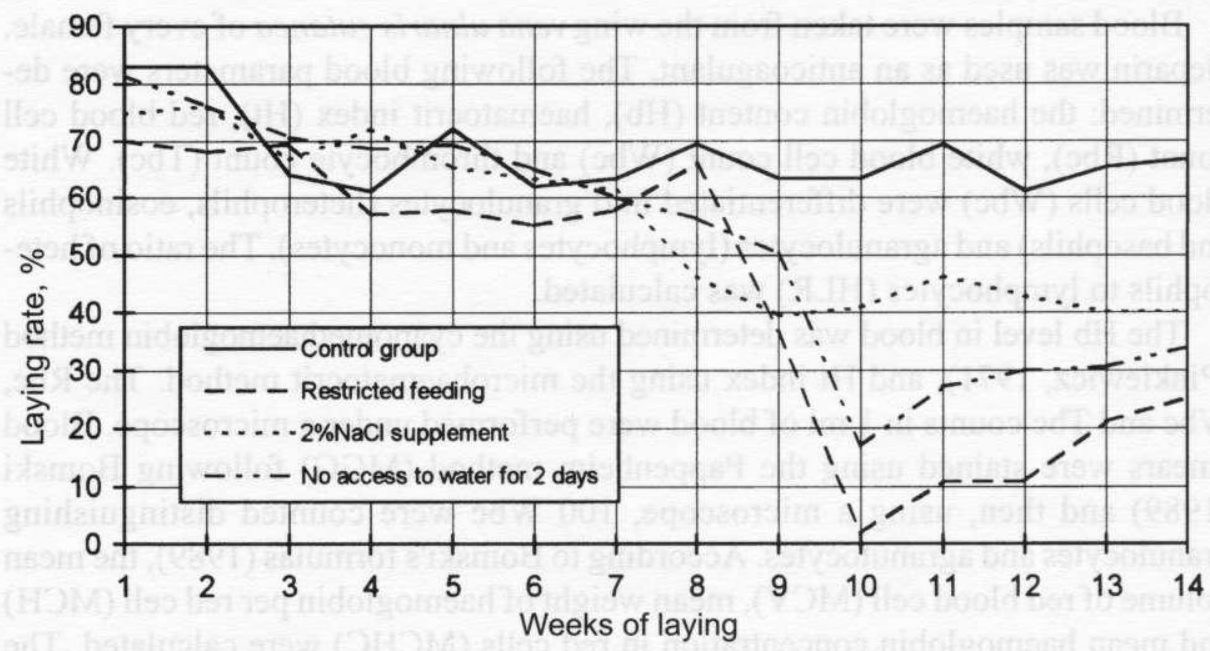

Figure 1. Effects of different stressors on laying rate in 4 groups of ducks

TABLE 1

The average laying rate LR of ducks (in \%) in different experimental periods

\begin{tabular}{lcccc}
\hline Group & \multicolumn{3}{c}{ Weeks } \\
\cline { 2 - 5 } & $1-8$ & 9 & $10-14$ & $(1-8)-(10-14)$ \\
\hline I & $69.7^{\mathrm{a}}$ & $63.3^{\mathrm{a}}$ & $65.2^{\mathrm{a}}$ & $4.5 \mathrm{~b}$ \\
II & $62.7^{\mathrm{a}}$ & $36.7^{\mathrm{b}}$ & $14.0^{\mathrm{c}}$ & $48.7^{*} \mathrm{a}$ \\
III & $65.7^{\mathrm{a}}$ & $39.5^{\mathrm{b}}$ & $42.0^{\mathrm{b}}$ & $23.7^{*} \mathrm{ab}$ \\
IV & $68.8^{\mathrm{a}}$ & $50.3^{\mathrm{ab}}$ & $27.8^{\mathrm{bc}}$ & $41.0^{*} \mathrm{a}$ \\
SEM & 7.3 & 6.3 & 6.1 & \\
\hline
\end{tabular}

* - mean LR in $1-8$ week significantly different from 10 -14 week at $\mathrm{P} \leq 0.05$

$\mathrm{a}, \mathrm{b}-$ mean values in columns followed by different letters are statistically different at $\mathrm{P} \leq 0.05$ SEM - standard error of the mean

stressing, as well as in relation to the control group. No statistically significant changes after applying stress were found in relation to MCV in any of the examined groups of ducks. However, $\mathrm{MCH}$ in group II and MCHC in group IV increased significantly.

After applying stress, Tbc, Wbc and granulocytes counts increased in all groups of ducks (Table 3). The highest number of granulocytes was observed in the blood of ducks in group IV. Also the number of agranulocytes increased (significantly only in group III). Mean numbers of granulocytes were higher and agranulocytes lower in group IV than in the remaining groups. 
Haematological indices in blood of ducks measured before (A) and after (B) applying of different stressors

\begin{tabular}{|c|c|c|c|c|c|c|c|c|c|c|c|c|}
\hline \multirow[t]{2}{*}{ Group } & \multicolumn{2}{|c|}{$\begin{array}{c}\mathrm{Rbc} \\
10^{12} / \mathrm{L}\end{array}$} & \multicolumn{2}{|c|}{$\begin{array}{c}\mathrm{Hb} \\
\mathrm{mmol} / \mathrm{L}\end{array}$} & \multicolumn{2}{|c|}{$\begin{array}{l}\mathrm{Ht} \\
\%\end{array}$} & \multicolumn{2}{|c|}{$\begin{array}{l}\text { MCV } \\
\text { fmol }\end{array}$} & \multicolumn{2}{|c|}{$\begin{array}{l}\mathrm{MCH} \\
\text { fmol }\end{array}$} & \multicolumn{2}{|c|}{$\begin{array}{c}\mathrm{MCHC} \\
\mathrm{mmol} / \mathrm{L}\end{array}$} \\
\hline & A & B & A & B & A & B & A & B & A & B & A & B \\
\hline I & $2.84^{a}$ & $2.83^{\mathrm{ab}}$ & $7.46^{\mathrm{a}}$ & $7.22^{b}$ & $39^{\mathrm{a}}$ & $40^{b}$ & $138.6^{\mathrm{b}}$ & $141.8^{\mathrm{a}}$ & $2.61^{a}$ & $2.58^{\mathrm{a}}$ & $18.9^{\mathrm{a}}$ & $18.2^{\mathrm{a}}$ \\
\hline II & $2.82^{\mathrm{a}}$ & $2.75^{\mathrm{b}}$ & $7.14^{a}$ & $7.41^{\mathrm{ab}}$ & $40^{\mathrm{a}}$ & $41^{\mathrm{ab}}$ & $141.8^{a b}$ & $148.4^{\mathrm{a}}$ & $2.53^{\mathrm{aab}}$ & $2.69^{* a}$ & $17.9^{b}$ & $18.1^{\mathrm{a}}$ \\
\hline III & $2.80^{a}$ & $2.84^{\mathrm{ab}}$ & $7.04^{* a}$ & $7.43^{* a b}$ & $40^{\mathrm{a}}$ & $41^{\mathrm{ab}}$ & $144.8^{\mathrm{a}}$ & $146.7^{\mathrm{a}}$ & $2.52^{\mathrm{ab}}$ & $2.64^{a}$ & $17.4^{b}$ & $18.0^{\mathrm{a}}$ \\
\hline IV & $2.83^{* a}$ & $3.01^{* a}$ & $6.95^{\circ a}$ & $7.77^{* a}$ & $40^{* a}$ & $43^{* a}$ & $140.7^{\mathrm{ab}}$ & $142.3^{\mathrm{a}}$ & $2.46^{\mathrm{b}}$ & $2.59^{\mathrm{a}}$ & $17.4^{\circ b}$ & $18.2^{*^{\circ}}$ \\
\hline SEM & 0.06 & 0.06 & 0.22 & 0.18 & 0.008 & 0.008 & 1.8 & 3.7 & 0.05 & 0.07 & 0.3 & 0.2 \\
\hline
\end{tabular}

* - mean A and B values differ significantly at $\mathrm{P} \leq 0.05$

$\mathrm{a}, \mathrm{b}-$ as in Table 1 
TABLE 3

Numbers of trombocytes (Tbc) and white blood cells (Wbc) in blood of ducks, measured before (A) and after (B) applying of different stressors

\begin{tabular}{|c|c|c|c|c|c|c|c|c|}
\hline \multirow{3}{*}{ Group } & & & \multicolumn{6}{|c|}{ Wbc, $10^{9} / \mathrm{L}$} \\
\hline & \multicolumn{2}{|c|}{ Tbc, $10^{9} / \mathrm{L}$} & \multicolumn{2}{|c|}{ granulocytes } & \multicolumn{2}{|c|}{ agranulocytes } & \multicolumn{2}{|c|}{ total } \\
\hline & A & B & A & B & A & B & A & B \\
\hline I & $27.7^{* a}$ & $35.7^{* i 1}$ & $7.3^{*}$ & $10.7^{* b}$ & $12.2^{\mathrm{a}}$ & $14.8^{\mathrm{a}}$ & $19.5^{*}$ & $25.5^{*} ;$ \\
\hline II & $29.3^{* *}$ & $34.9^{* * a}$ & $6.7^{* a}$ & $9.3^{\circ} \mathrm{b}$ & $11.5^{\mathrm{a}}$ & $13.6^{\mathrm{a}}$ & $18.2^{*_{a t}}$ & $22.9^{*}$ \\
\hline III & $27.1^{\mathrm{a}}$ & $32.3^{a}$ & $6.6^{\circ}$ & $9.5^{\circ b}$ & $10.3^{*_{\mathrm{B}}}$ & $13.7^{* a}$ & $16.9^{*_{\text {i }}}$ & $23.2^{* a}$ \\
\hline IV & $26.1^{*}$ & $33.7^{\circ}$ & $7.7^{\circ}$ & $15.6^{\circ}$ & $10.9^{\circ}$ & $9.2^{\mathrm{b}}$ & $18.6^{* i+}$ & $24.8^{*}$ d \\
\hline SEM & 1.8 & 1.9 & 0.7 & 0.9 & 0.9 & 1.3 & 1.3 & 1.5 \\
\hline
\end{tabular}

* - as in Table 2

$\mathrm{a}, \mathrm{b}-\mathrm{as}$ in Table $\mathrm{l}$

TABLE 4

Percentage ratio of white blood cells in blood of ducks, measured before (A) and after (B) applying of different stressors

\begin{tabular}{|c|c|c|c|c|c|c|c|c|c|c|}
\hline \multirow{3}{*}{ Group } & \multicolumn{6}{|c|}{ Granulocytes, \% } & \multicolumn{4}{|c|}{ Agranulocytes, \% } \\
\hline & \multicolumn{2}{|c|}{ basophils } & \multicolumn{2}{|c|}{ eosynophils } & \multicolumn{2}{|c|}{ heterophils } & \multicolumn{2}{|c|}{ lymphocytes } & \multicolumn{2}{|c|}{ monocytes } \\
\hline & $\mathrm{A}$ & $\mathrm{B}$ & $\mathrm{A}$ & $\mathrm{B}$ & $\mathrm{A}$ & $\mathrm{B}$ & $\mathrm{A}$ & B & $\mathrm{A}$ & $\mathrm{B}$ \\
\hline I & $0.9^{\mathrm{a}}$ & $1.3^{\mathrm{i}}$ & $2.5^{\prime \prime}$ & $2.4^{\prime \prime}$ & 34.6 & $38.4^{\prime}$ & $57.7^{\circ}$ & $54.0^{\prime \prime}$ & $4.3^{a}$ & $3.9^{\mathrm{ab}}$ \\
\hline II & $1.1^{\mathrm{a}}$ & $1.3^{\mathrm{a}}$ & $2.4^{4}$ & $2.4^{\prime \prime}$ & $33.7^{\mathrm{a}}$ & $39.1^{11}$ & $57.7^{\prime \prime}$ & $54.2^{i}$ & $5.1^{\mathrm{*a}}$ & $3.0^{* \mathrm{tb}}$ \\
\hline III & $0.9^{\mathrm{a}}$ & $1.1^{\mathrm{n}}$ & $2.7^{a}$ & $2.3^{a}$ & $35.3^{\mathrm{a}}$ & $37.7^{4}$ & $57.3^{\prime \prime}$ & $54.9^{a}$ & $3.8^{\mathrm{a}}$ & $4.0^{\text {at }}$ \\
\hline IV & $0.9^{\mathrm{a}}$ & $1.0^{\mathrm{a}}$ & $3.8^{*}$ & $3.5^{\mathrm{b}}$ & $36.7^{*}$ & $60.5^{* b}$ & $54.2^{*_{i l}}$ & $30.1^{* h}$ & $4.4^{4}$ & $4.9^{\prime \prime}$ \\
\hline SEM & 0.2 & 0.2 & 0.5 & 0.4 & 2.4 & 3.2 & 4.6 & 3.1 & 0.8 & 0.6 \\
\hline
\end{tabular}

* - as in Table 2

$\mathrm{a}, \mathrm{b}-\mathrm{as}$ in Table 1

In Table 4 the proportion of different kinds of granulocytes and agranulocytes in the blood of ducks before and after stress is shown. In group IV, a statistically significant increase of the heterophile concentration from 36.7 to $60.5 \%$ and decrease of the lymphocyte concentration from 54.2 to $30.1 \%$ were observed. These values differed significantly from those found in the remaining groups. In group II, a significant decrease in the monocyte concentration from 5.1 to $3.0 \%$ was found.

The heterophil : lymphocyte ratio increased in the blood of ducks in all of the examined groups (Table 5). The highest value of this index was calculated in group IV. The concentration of corticosterone in blood after stress was lower in group II, and higher in groups III and IV ( $\mathrm{P} \leq 0.05)$ than in the control group. 
TABLE 5

Heterophil : lymphocyle ratio (HLR) and corticosterone level (CN) in blood of ducks, measured before (A) and after (B) applying of different stresors

\begin{tabular}{llcc}
\hline Group & \multicolumn{2}{c}{ Heterophil/lymphocyte ratio } & $\begin{array}{c}\text { Corticosterone } \\
\mathrm{ng} / \mathrm{mL}\end{array}$ \\
\cline { 2 - 4 } & $\mathrm{A}$ & $\mathrm{B}$ & $\mathrm{B}$ \\
\hline I & $0.65^{\mathrm{a}}$ & $0.85^{\mathrm{a}}$ & $29.3^{\mathrm{b}}$ \\
II & $0.68^{\mathrm{a}}$ & $0.93^{\mathrm{a}}$ & $15.7^{\mathrm{c}}$ \\
III & $0.66^{\mathrm{a}}$ & $0.75^{\mathrm{a}}$ & $42.4^{\mathrm{a}}$ \\
IV & $0.74^{\mathrm{a}}$ & $2.63^{\mathrm{b}}$ & $44.5^{\mathrm{a}}$ \\
SEM & $0.08^{\mathrm{a}}$ & 0.21 & $4.0^{2}$ \\
\hline
\end{tabular}

* - as in Table 2

$\mathrm{a}, \mathrm{b}-$ as in Table 1

\section{DISCUSSION}

The laying capability of ducks is a low heritability trait and is affected, to a considerable degree, by environmental factors (Kontecka, 1979). The performed investigations showed a substantial decrease in laying rate (differences between periods $48.7 \%$ ) in group II in which the birds were given a limited amount of feed and in group IV $(41 \%)$ in which ducks were deprived of water (Table 1$)$. The $2 \%$ concentration of $\mathrm{NaCl}$ in the feed had a less negative effect on the laying rate of ducks than the remaining stressing factors. These results are in accordance with studies of Härtel et al. (1991), who used different levels of $\mathrm{NaCl}$ (from 0.25 to $2 \%$ ) in feed for laying hens and observed a decrease in the laying rate only when the feed contained $2 \% \mathrm{NaCl}$.

The performed investigations revealed statistically significant changes in the values of $\mathrm{Rbc}, \mathrm{Hb}$ and $\mathrm{Ht}$ counts only in group IV, in which for 2 days ducks had no access to water (Table 2). Maxwell et al. (1990) did not find significant effects of restricted feeding on the discussed blood indices. However, they showed a decrease in most of the indices, with the exception of the Rbc count. The number of $\mathrm{Rbc}$ in our work was higher in all groups and MCV lower than those found by Kontecka et al. (1995) in their experiments on one year old Peking ducks in the same period of the reproductive season but in the second year of their reproductive utilization. Wbc and Tbc counts increased significantly in blood in all groups, including the control. The increase in the number of these cells, as well as in values of HLR was probably caused by the response of the birds to stress connected with catching ducks and sampling their blood, as confirmed by the observations of Jones et al. (1988).

In all groups, a statistically significant increase of granulocyte numbers was observed (Table 3). Also the number of agranulocytes increased, with the excep- 
tion of group IV (no access to water). However, this increase was statistically significant only in group III fed the diet supplemented with $\mathrm{NaCl}$. In the group in which ducks received the ration that covered only about $25 \%$ of their daily requirement, a non-significant increase of HLR and a lower level of $\mathrm{CN}$ was recorded (Table 5). In studies by Freeman et al. (1983) the level of $\mathrm{CN}$ in the blood plasma of chickens during a period of restricted feeding initially increased and then subsided. This also pertains to HLR values. In experiments carried out by Gross and Siegel (1986), as well as by Katanbaf et al. (1988) a similar response of chickens was observed, i.e. adaptation to intervals in the feed intake. Maxwell et al. (1992), when carrying out studies on ducks fed in the period from the 2 nd to 21 st week of life, amounts of diet limited to $25 \%$ of ad libitum intake found that the HLR value increased in the first week. In the following weeks of restricted feeding, a decrease in heterophil and eosinophil and an increase of basophil and trombocyte counts were observed. According to Maxwell and Robertson (1995), the ratio of heterophils to lymphocytes is a more reliable indicator of stress than the corticosterone concentration in blood. In the present investigations, a statistically significant increase of the HLR value was accompanied by the highest concentration of $\mathrm{CN}$ in the blood as a result of the strong stress caused by the 2-day withdrawal of water. However, Hocking et al. (1993) did not observe a significant increase in HLR and CN concentration in blood when they restricted chickens access to water for $2-3 \mathrm{~h}$ daily.

\section{CONCLUSIONS}

It can be concluded that food restriction exerted the longest and most negative influence on the laying rate of ducks. On the other hand, the two-day withdrawal of water was found to be very stressful, as confirmed by high values of HLR and $\mathrm{CN}$, commonly regarded as physiological indicators of the occurrence of stress. An increased $\mathrm{NaCl}$ concentration in the diet had a smaller effect, both on the laying rate and on HLR values.

\section{REFERENCES}

Bomski A., 1989. Basal Haematological Investigations (in Polish). PZWL, Warszawa, pp. 56-182 Freeman B.M., Manning A.C.C., Flack I.H., 1983. Adrenal cortical activity in the domestic fowl, Gallus domesticus, following withdrawal of water or food. Comp. Biochem. Physiol. 74A, 639-641

Gross W.B., Siegel H.S., 1986. Effects of initial and second periods of fasting on heterophil/ limphocyte ratios and body weight. Avian Dis. 30, 345-346 
Härtel H., 1991. Mangel und Exzess von Natriumchlorid in Legehennenrationen 2. Mitteilung: Untersuchungen zur Salztoleranz der Legenhenne. Arch. Geflügelk. 55, 38-46

Hocking P.M., Maxwell M.H., Mitchell M.A., 1993. Welfare assessment of broiler breeder and layer females subjected to food restriction and limited access to water during rearing. Brit. Poultry Sci. $34,443-458$

Jones R.B., Beuving G., Blokhuis H.J., 1988. Tonic immobility and heterophil/lymphocyte responses of the domestic fowl to corticosterone infusion. Physiol. Behav. 42, 249-253

Katanbaf M.N., Jones D.E., Dunnington E.A., Gross W.B., Siegel P.B., 1988. Anatomical and physiological responses of early and late feathering broiler chicken to various feeding regimes. Arch. Geflügelk. 52, 119-126

Kontecka H., 1979. Genetical indices of Pekin ducks breeding in Poland (in Polish). Rocz. AR Poznań, 111, 26, 95-104

Kontecka H., Książkiewicz J., Cegielska E., 1995. Changes in the values of haematological indices in season and their connection with reproduction traits in ducks. In: Proceedings of 10 th European Symposium on Waterfowl, Halle (Germany), pp. 209-212

Maxwell M.H., 1993. Avian blood leucocyte responses to stress. World Poultry Sci. J. 49, 34-43

Maxwell M.H., Hocking P.M., Robertson G.W., 1992. Differential leucocyte responses to various degrees of food restriction in broilers, turkeys and ducks. Brit. Poultry Sci. 33, 177-187

Maxwell M.H., Robertson G.W., 1995. The avian basophilic leukocyte: a review. World Poultry Sci. J. 51, 307-325

Maxwell M.H., Robertson G.W., Spence S., McCorquodale C.C., 1990. Comparison of haematological values in restricted and ad libitum-fed domestic fowls: red blood cell characteristics. Brit. Poultry Sci. 31, 407-413

Mitchell M.A., Kettlewell P.J., Maxwell M.H., 1992. Indicators of physiological stress in broiler chickens during road transportation. Anim. Welfare 1, 91-103

Pinkiewicz E., 1971. Basal Clinical Investigations in Animal Diseases (in Polish). PWRiL, Warszawa, pp. $15-26$

Zulkifli I., Siegel P.B., 1995. Is there a positive side to stress? World Poultry Sci. J. 51, 63-71

\section{STRESZCZENIE}

\section{Wpływ różnych czynników stresujących na nieśność i wartość wybranych wskaźników krwi u kaczek reprodukcyjnych}

Badano wpływ kilku czynników stresujących na nieśność, a także na wartość wskaźników hematologicznych i poziom kortykosteronu we krwi kaczek. Doświadczenie przeprowadzono w okresie reprodukcji (kwiecień-lipiec) na 84 kaczkach pekin podzielonych na 4 grupy. Wszystkie ptaki żywiono przez 8 tygodni standardową mieszanką pełnoporcjową do woli. W 9 . tygodniu od kaczek pobrano krew i zastosowano następujące czynniki powodujące stres przez jeden tydzień: grupa II żywienie ograniczone: $70 \mathrm{~g}$ paszy na 1 sztukę dziennie, grupa lII - żywienie mieszanką z dodatkiem $20 \mathrm{~g} \mathrm{NaCl} / \mathrm{kg}$, grupa IV - kaczki pozbawiono dostępu do wody przez dwa dni. W 10 . tygodniu od kaczek ponownie pobrano krew i w czasie następnych 5 tygodni wszystkie grupy żywiono do woli. We krwi oznaczano: hemoglobinę, hematokryt, liczbę krwinek czerwonych i białych (udział granulocytów i agranulocytów) oraz poziom kortykosteronu. Przez cały okres trwający 14 tygodni codzicnnic rejestrowano liczbę zniesionych jaj. 